\title{
International Law of the Sea: An Overlook and Case Study
}

\author{
Arif Ahmed \\ Department of Law and Justice, Southeast University, Dhaka, Bangladesh \\ Email: lawarif73@yahoo.com
}

How to cite this paper: Ahmed, A. (2017) International Law of the Sea: An Overlook and Case Study. Beijing Law Review, 8, 2140. https://doi.org/10.4236/blr.2017.81003

Received: December 23, 2016

Accepted: March 4, 2017

Published: March 7, 2017

Copyright (C) 2017 by author and Scientific Research Publishing Inc. This work is licensed under the Creative Commons Attribution-NonCommercial International License (CC BY-NC 4.0). http://creativecommons.org/licenses/by-nc/4.0/

\begin{abstract}
Sea is a large body of water that is surrounded by the land. It is a crucial part of human trade and commerce, voyage, mineral extraction, power generation and is also considered as an essential source of blue economy nowadays. International law of the sea is a law of maritime space that peacefully settles the global disputes on maritime boundary between or among the States and defines various jurisdictions of the maritime zones as well as the rights and obligations of the coastal States in these zones, especially with regard to the conservation of marine environment and biodiversity. The key objective of this piece of academic research is to demonstrate a brief overview of the international law of the sea with a special emphasize on the sources and legal framework of this law. This study also strives to focus the civil and criminal liability, jurisdictions, rights and obligations of the coastal states with regard to the different maritime zones. Furthermore this study delineates the rules and extent of using these maritime zones in the light of various treaty provisions on the international law of the sea where different adjudicated cases are also presented along with a profound scrutiny upon their fact, issues, judgment and reasoning.
\end{abstract}

\section{Keywords}

Coastal State, Convention, International Law, Maritime, Sea

\section{Introduction}

International law of the sea is that part of public international law that regulates the rights and obligations of States and other subjects of international law, regarding the use and utilization of the seas in peace time (Brown, 1994). It is distinguished from the private maritime law that regulates the rights and obligations of private persons with regard to maritime matters, e.g., the carriage of goods and maritime insurance (Churchill \& Lowe, 1999). Law of the sea was de- 
veloped as part of the law of nations in the $17^{\text {th }}$ century with the emergence of the modern national State system (O'Connell, 1982). The seas of the world have historically played two key roles: firstly, as a means of communication, and secondly, as an immense reservoir of both living and non-living natural resources. Both of these roles have encouraged the development of legal rules (Shaw, 1997: p. 390). No branch of international law has undergone more radical changes during the past four decades than has the law of the sea and maritime highways (Starke, 1994: p. 242). Law of the sea is concerned with the public order at sea and much of this law is codified in the UN Convention on the Law of the Sea (UNCLOS) (Churchill, 2013).

In the international jurisdictions disputes may frequently be arisen among the neighboring coastal States regarding the delimitation of maritime boundary, exploitation of minerals or natural resources, commission of any crime in the territorial boundary of another State, etc. These disputes are generally resolved by the international courts or tribunals on the basis of complaints filed by the parties concerned following the rules of international law of the sea or following the precedents as a pivotal source of international law. This study, however, is concerned with those rules of international law usually referred to as "the law of the sea" and is intended as a starting point for research on the law of the sea. This research work especially deals with the broader area of the sea law that evidently involves consideration of matters mainly of the base line, inland waters, territorial sea, contiguous zone, Exclusive Economic Zone (EEZ), high sea and continental shelf.

\section{Research Methodology}

The paper is descriptive in nature which is actually based on a short research. Having regard to the nature of the article, in preparing the same, analytical method has been resorted to. It is entirely based on the secondary sources collected from Text-books on International Law, Journals Articles, Newspapers, Adjudicated Cases, and Websites etc. The collected sources have been presented in past form in order to make the study more informative, analytical and useful for the readers. Also in this study the contemporary adjudicated cases on international law of the sea are elaborately explained so that the jurisdiction, rights and obligations of different subjects of international law can plainly be understood.

\section{International Law of the Sea: Legal and Institutional Framework}

It should not be wise to presume that the law of the sea is to be found only in one place; rather the present law is a mixture of customary international law and treaty law, both bilateral and multilateral.

\subsection{The Four Geneva Conventions on Territorial Waters and Contiguous Zone, 1958}

The first UN Conference on the law of the sea was held in 1958 in Geneva. In 
this conference four multilateral conventions covering various aspects on the law of the sea were adopted: 1) Convention on the Territorial Sea and Contiguous Zone; 2) Convention on the High Seas; 3) Convention on Fishing and Conservation of Living Resources; and 4) Convention on the Continental Shelf. All these conventions are in force, though in many aspects they have been superseded by the 1982 UN Convention on the Law of the Sea which is mainly of general application, i.e., it is not confined to one specific aspect of the law of the sea. For non-parties to the 1982 Convention and for those matters on which the 1982 Convention is silent, the 1958 Conventions will continue to govern the relations of States that have ratified them. For States that are neither party to the 1982 Convention nor to the 1958 Conventions, the relevant law is the customary (Dixon, 2005: p. 196).

\subsection{The UN Convention on the Law of the Sea (UNCLOS, 1982)}

The 1982 Convention on the Law of the Sea constitutes a comprehensive codification and development of contemporary international law governing the sea in time of peace (Abdurrahim, 2012). The UNCLOS, also called the Law of the Sea Convention, is a global agreement that resulted from the third UN Conference on the Law of the Sea (UNCLOS III), which took place between 1973 and 1982. This treaty is considered to be the "constitution of the oceans" and represents the result of an unprecedented, and so far never replicated, effort at codification and progressive development of international law (Treves, 2013). Maritime jurisdictions are now governed mainly by the 1982 UN Convention on the Law of the Sea. The comprehensive 1982 Convention that replaced the 1958 four conventions on the law of the sea consists of 320 articles and 9 annexure was concluded in 1982. The UNCLOS is intended to govern the use of oceans for fishing, shipping, exploration, navigating and mining and it is the most complete treaty in public international law that covers a range of law of the sea topics, e.g. delimitation of maritime boundaries, maritime zones, marine environment protection, marine scientific research, piracy and so on. This Convention represents the most significant development in the whole history of the rules of international law regarding the high seas (Starke, 1994: p. 242). The greater part of the convention, containing the more significant rules therein enunciated much the previous law was thereby changed; appear now to command the general consensus of the world community.

\subsection{Salient Features: The UN Convention on the Law of the Sea, 1982}

A careful list of the main substantive provisions of the Convention, focusing on those, introduces changes or new concepts in the traditional law of the sea would seem to include the aspects (Treves, 2013): a) The maximum width of the territorial sea is fixed at 12 miles and that of the contiguous zone at 24 miles; b) A "transit passage" regime for straits used for international navigation is established; c) States consisting of archipelagos, provided certain conditions are satis- 
fied, can be considered as "archipelagic States", the outermost islands being connected by "archipelagic baselines" so that the waters inside these lines are archipelagic waters; d) A 200-mile exclusive economic zone including the seabed and the water column, may be established by coastal States in which such States exercise sovereign rights and jurisdiction on all resource-related activities; e) Other States enjoy in the exclusive economic zone high seas freedoms of navigation, over flight, laying of cables and pipelines and other internationally lawful uses of the sea connected with these freedoms; f) A rule of mutual "due regard" applies to ensure compatibility between the exercise of the rights of the coastal states and of those of other states in the exclusive economic zone; g) The concept of the continental shelf has been confirmed, though with newly defined external limits; h) The International Seabed Authority being the "machinery" entrusted with the supervision and regulation of exploration and exploitation of the resources; i) A series of very detailed provisions deal with the protection of the marine environment setting out general principles and rules about competence for law-making and enforcement as well as on safeguards; $j$ ) Detailed provisions concerning marine scientific research, based on the principle of consent of the coastal State, consent which should be the norm for pure research and discretionary for resource-oriented research; k) The ocean bottom beyond national jurisdiction is proclaimed to be the "Common Heritage of the Mankind" (Khan, 2006).

\subsection{Bilateral/Multilateral Treaties or Customary International Law}

Besides the above mentioned two vital international instruments, the customary international law and other bilateral or multilateral agreements are also the outstanding source of international law of the sea. Regarding the customary international law, it is already noted that the 1958 and 1982 UN Conventions on the Law of the Sea have contributed a lot to the development of the customary international laws. There may be other rules of customary international law that may not precisely be reflected in any conventional text nor owe their origin to incorporation in such a text. These as with all customary rules, bind States in the ordinary manner (Dixon, 2005: p. 198).

\subsection{International Tribunal for the Law of the Sea (ITLOS)}

After the entry into force of the UN Convention on the Law of the Sea on $16^{\text {th }}$ November, 1994 strong efforts were made for the establishment of an International Tribunal for the Law of the Sea (ITLOS). In August 1996, 21 Judges of the Tribunal were elected on the basis of "equitable geographical distribution". The ITLOS is an intergovernmental organization created by the mandate of the Third UN Conference on the Law of the Sea. It was established by the UN Convention on the Law of the Sea, signed at Montego Bay, Jamaica, on $10^{\text {th }}$ December, 1982. The ITLOS was ultimately established on $21^{\text {st }}$ October, 1996 of which jurisdiction is not compulsory and is optional or based on the consent of the 
States. The Tribunal consists of 21 members, elected from among the highest reputation of fairness and integrity and a recognized competence in the field of the law of the sea (Kapoor, 2008: p. 153). The Tribunal is situated in Germany, established a global framework for law over "all ocean space, its uses and resources". The Tribunal is open to all the state parties to the 1982 UN Convention on the Law of the Sea.

\section{UNCLOS: Various Jurisdictions of the Maritime Zones}

Under both the Geneva Convention on Territorial Sea, 1958 and the UN Convention on the Law of the Sea, 1982 there are following seven maritime areas over which the States can exercise their jurisdiction:

1) Base Line;

2) Inland waters;

3) Territorial Sea;

4) Contiguous Zone;

5) Exclusive Economic Zone (EEZ);

6) High Seas; and

7) Continental shelf.

\subsection{The Base Line}

The coastal curve, from which the maritime area of a State is measured, is called baseline or low water line (Rahman, 2003: p. 145). Baseline can be of two types: a) normal baseline and b) straight baseline. Normal baseline is the low-water mark line along the coast. The low-water mark after ebb tide on the coast is considered the normal baseline. It is a line hugging the coast. Article 5 contains provisions as to normal baseline and reveals that, except where otherwise provided in this Convention, the normal baseline for measuring the breadth of the territorial sea is the low-water line along the coast as marked on large scale charts officially recognized by the coastal State. On the other hand, straight baseline departs from the physical coastline due to certain distinctive features of coasts of a State (Khan, 2007: p. 227).

Article 12 (1) and (2) of the 1958 Convention contains provisions as to the delimitation of the baseline and states that, where the coasts of two States are opposite or adjacent to each other, neither of the two States is entitled, failing agreement between them to the contrary, to extend its territorial sea beyond the median line every point of which is equidistant from the nearest points on the baselines from which the breadth of the territorial seas of each of the two States is measured. The provisions of this paragraph shall not apply where it is necessary by reason of historic title or other special circumstances to delimit the territorial seas of the two States in a way which is at variance with this provision. The line of delimitation between the territorial seas of two States lying opposite to each other or adjacent to each other shall be marked on large-scale charts officially recognized by the coastal States. The globally recognized principle as to the delimitation of straight baseline is accepted in 1951 from the judgment of the 
famous Anglo-Norwegian Fisheries Jurisdiction Case (1951) (England vs. Norway; ICJ).

In this case, the Norwegian government delimited its fisheries zone (territorial sea) by a decree of $12^{\text {th }}$ July, 1935 . The area of this delimitation was about thousand miles of coastland of its 66.28.2 North Latitude. The Norwegian limit of four miles of territorial waters had been established by a Royal decree in 1812 and the UK also admitted it. But it was not measured from the low water mark at every point. Linking the out most point of land and sometimes drying rocks above water only at high tide. The UK recognizing the Norwegian claim of four miles challenged the validity of the baseline newly made and laid their grievance in the ICJ for adjudication. The issue in this case before the Court was whether the base lines fixed by the said decree in application of the Norwegian method were contradictory to the international law. The Court decided by a vote 10 to 2 in favor of Norway approving the Norwegian practice of drawing an outer line for its territorial sea that was based on straight base lines following the general directions of the coast but not the indentation of that coast. According to the Court the following reasons were considered to reach the decision:

1) In respect of delimitation of territorial waters with other States the ICJ observed that the act of delimitation is always an international aspect, it cannot be dependent merely upon the will of coastal State as expressed in the domestic law. 2) The coastline of Norway is not one of ordinary nature; rather it is of a broken nature. The Court held that the method of baselines employed by Norway was not contrary to the international law; inter alia, the special geographical facts involved and the economic interests peculiar to the region.

The case is mainly based on the principle that, in some situations geographical circumstances permit the drawing of straight baseline in the territorial sea. This method consists of selecting appropriate points on the low water mark and drawing straight lines between them. The decision of this case was subsequently accepted by the world community and was incorporated in the 1958 Geneva Convention on Territorial Sea and Contiguous Zone.

\subsection{The Inland Waters}

The internal waters which exist from the baseline to the landward side area of the coastal State are called the inland waters. Article 8 (1) of the 1982 Convention states that, waters on the landward side of the baseline of the territorial sea form part of the internal waters of the State. Also article 5 (1) of the 1958 Convention provides that, waters on the landward side of the baseline of the territorial sea form part of the internal waters of the State.

\section{Civil and Criminal Jurisdiction of the Coastal State}

The coastal State has its sovereign control and authority over its inland waters. The coastal state also has the civil and criminal jurisdiction over its internal waters. If the law and order situations in the inland waters of the coastal area are hampered, it shall definitely apply its criminal jurisdiction. There is a renowned case in this regard e.g., the Fijens Case or Wildenhus Case (1887) (Belgium vs. 
USA) which has already been discussed in the previous chapter. Another leading case in this respect is Rex vs. Anderson (1868).

In this case, James Anderson was an American national killed a foreign national in a British ship and at the time of that killing the vessel was in the French territorial water. That is to say, in this case the accused was an American citizen, vessel was of Britain and the place of committing crime was France. When a case is filed before the British Court, Anderson claimed and argued that the crime was occurred in the French territorial water and for this reason Britain has no jurisdiction to try the accused in this. The main issue before the Court was whether the British Court has actually jurisdiction to try Anderson. The Appellate Court decided that, the three countries involved in this case are entitled to prosecute Anderson and so can Britain in order to protect its vessel. The reason behind this judgment was that, Britain has jurisdiction to prosecute Anderson because the crime was committed in the British ship, i.e. here the flag State is Britain. Again, the USA has also Personal Jurisdiction to prosecute Anderson and France can also prosecute as it has the Territorial Jurisdiction as the crime has hampered the security and peace of France.

State vs. Yannopulous (1974) (Italy vs. Greece) is another relevant case here. In this case, Yannopulous was a Greek national. He was one of the members of crew of a ship belong to Cypress. The ship was anchored in an Italian port with huge quantity marijuana. Carrying marijuana is itself an offence. Yannopulous was arrested and sent to the court alleging that his carrying of the marijuana was a threat to the peace and security in the shore. The issue in this case was whether Italy had the jurisdiction to try Yannopulous for the alleged offence? The Italian Court acquitted Yannopulous with honor and set him free. In this case, the main reasoning before the court was as follows:

1) Under the customary international law the coastal state has both the civil and criminal jurisdiction in its internal matters. But if the offence is committed on board of the vessel, the flag state has the jurisdiction, which is concurrent to that of the state whose national was the offender. 2) There is an exception to this general rule, which provides that if the offence disturbed the peace, security and good order of the shore, the coastal state can try such offence on the ground of public interest. 3) There is no evidence in this case that the act of Yannopulous disturbed the peace, security and good order of the port. Though Yannopulous was found and arrested with drugs, his council argued that he only possessed it and had no intention or motive to sell. It would be determined unilaterally by the coastal state whether an act of an alien affects the peace, security and good order of that port or that country.

\subsection{The Territorial Sea}

The doctrine of territorial sea has traditionally been regarded as founded upon the principle laid down by the Dutch Jurist Bynkershoek in his de dominion maris dissertation in 1702 that a state's sovereignty extended as far out to sea as a common shot would reach and the three-mile limit has traditionally been 
represented as simply rough equivalent of the maximum range of a canon shot in the $18^{\text {th }}$ century (Sircar, 1997: p. 56). Actually the territorial sea is the closest maritime area adjacent to the land territory of states (Khan, 2007: p. 228). The territorial sea forms an undeniable part of the land territory to which it is bound, so that a cession of land will automatically include any band of territorial waters (Brown, 1994).

\subsubsection{Legal Position of the Coastal State}

Ordinarily the states claimed only three miles of territorial sea till the 1960s and there was no uniformity in the national jurisdictions of the territorial sea. The 1982 Convention has put to rest all varying width of the territorial sea. According to article 1 of the 1958 Convention, the sovereignty of a state extends beyond its land territory and internal waters, to a belt of sea adjacent to its coast. As per article 2(1) of the 1982 UN Convention, the sovereignty of a coastal state extends, beyond its land territory and internal waters and, in the case of an archipelagic state, its archipelagic waters, to an adjacent belt of sea, described as the territorial sea. This sovereignty extends to the air space over the territorial sea as well as to its bed and subsoil (Article $2(2), 1982)$. The sovereignty over the territorial sea is exercised subject to this Convention and to other rules of international law (Article 2 (3), 1982). According to article 3 of the 1982 Convention, every State has the right to establish the breadth of its territorial sea up to a limit not exceeding 12 nautical miles, measured from baselines determined in accordance with this Convention. The width of the territorial sea is defined from the low water mark around the coasts of the state (Reisman \& Westerman, 1992). In the area of territorial sea, the coastal state shall have its exclusive jurisdiction. But the other states shall enjoy an exceptional right named as "right of innocent passage".

\subsubsection{Right of Innocent Passage: Explanation of the Idea}

Article 17 of the 1982 Convention deals with the right of innocent passage of states and provides that, subject to this Convention, ships of all States, whether coastal or land-locked, enjoy the right of innocent passage through the territorial sea. The 1982 Convention also contains provisions regarding the meaning of 'passage' which in its article 18 (1) states that, passage means navigation through the territorial sea for the purpose of: a) traversing that sea without entering internal waters or calling at a roadstead or port facility outside internal waters; or b) proceeding to or from internal waters or a call at such roadstead or port facility. Passage shall be continuous and expeditious. Passage includes stopping and anchoring, but only in so far as the same are incidental to ordinary navigation or are rendered necessary by force majeure or distressor for the purpose of rendering assistance to persons, ships or aircraft in danger or distress (Article 18 (2)). Conversely, article 19 (1) provides the meaning of 'innocent passage' and accordingly states that, passage is innocent so long as it is not prejudicial to the peace, good order or security of the coastal State. Such passage shall take place in conformity with this Convention and with other rules of international law. The right 
to innocent passage shall no more remain innocent if the peace and security of the territorial sea of the coastal state is hampered by any act of the foreign vessel (Article 19 (2) (a) - (i), 1982).

\subsubsection{Obligations of the Coastal State}

The coastal state has some obligations regarding the innocent passage under the 1982 Convention. For instance, the coastal state shall enact necessary legislations regarding the right to innocent passage (Article 21 (1) - (4), 1982). That is to say, the obligation to ensure the security of innocent passage lies upon the coastal state (Article 22 (1)). Again, article 25 deals with the rights of protection of the coastal State which states in its sub article (1) that, the coastal State may take the necessary steps in its territorial sea to prevent passage which is not innocent. The coastal State may, without discrimination in form or in fact among foreign ships, suspend temporarily in specified areas of its territorial sea, the innocent passage of foreign ships if such suspension is essential for the protection of its security, including weapons exercises. Such suspension shall take effect only after having been duly published (Article 25 (3)).

\subsubsection{Coastal States' Criminal Jurisdiction: Vessels in Innocent Passage}

Article 27 deals with the provisions regarding the criminal jurisdiction on board a foreign ship and provides in its sub-article (1) that, the criminal jurisdiction of the coastal State should not be exercised on board a foreign ship passing through the territorial sea to arrest any person or to conduct any investigation in connection with any crime committed onboard the ship during its passage, save only in the following cases: a) If the consequences of the crime extend to the coastal State; b) If the crime is of a kind to disturb the peace of the country or the good order of the territorial sea; c) If the assistance of the local authorities has been requested by the master of the ship or by a diplomatic agent or consular officer of the flag State; or d) If such measures are necessary for the suppression of illicit traffic in narcotic drugs or psychotropic substances. The above provisions do not affect the right of the coastal State to take any steps authorized by its laws for the purpose of an arrest on board a foreign ship passing through the territorial sea after leaving internal waters (Article 27 (2), 1982). In considering whether or in what manner an arrest should be made, the local authorities shall have due regard to the interests of navigation (Article 27 (4)).

\subsubsection{Civil Jurisdiction of the of the Coastal State over the Vessels in Innocent Passage}

Article 28 of the 1982 Convention deals with the civil jurisdiction of the coastal state in relation to foreign ships which states as follows:

1) The coastal State should not stop or divert a foreign ship passing through the territorial sea for the purpose of exercising civil jurisdiction in relation to a person on board the ship. 2) The coastal State may not levy execution against or arrest the ship for the purpose of any civil proceedings, save only in respect of obligations or liabilities assumed or incurred by the ship itself in the course or for the purpose of its voyage through the waters of the coastal State. 3) Para (2) 
is without prejudice to the right of the coastal State, in accordance with its laws, to levy execution against or to arrest, for the purpose of any civil proceedings, a foreign ship lying in the territorial sea, or passing through the territorial sea after leaving internal waters.

\subsubsection{Provisions Regarding War Ships and Other Non-Trading Ships}

Article 30 deals with the provisions regarding non-compliance by warships with the laws and regulations of the coastal State and reveals that, if any warship does not comply with the laws and regulations of the coastal State concerning passage through the territorial sea and disregards any request for compliance therewith which is made to it, the coastal State may require it to leave the territorial sea immediately. According to article 31, the flag State shall bear global obligation for any loss or damage to the coastal State resulting from the non-compliance by a warship or other government ship operated for non-commercial purposes with the laws and regulations of the coastal State concerning passage through the territorial sea or with the provisions of this Convention or other rules of international law. The responsibility to keep the passage innocent is always of the coastal state.

\subsection{The Contiguous Zone}

The concept of contiguous zone (Lowe, 1981: p. 109) was virtually formulated as an authoritative and consistent doctrine in the 1930s by the French writer Gidel, and it appeared in the 1958 Convention on the Territorial Sea. Contiguous zone is that part of the sea which is beyond and adjacent to the territorial sea of the coastal state. It may not extend beyond 24 miles from which the width of the territorial sea is measured (Kapoor, 2008: p. 136). The use of contiguous zones gives the coastal state an additional area of jurisdiction for limited purposes (Dixon, 2005: p. 202). Article 33 of the 1982 Convention deals with contiguous zone and reveals in its sub-article (1) that, in a zone contiguous to its territorial sea, described as the contiguous zone, the coastal State may exercise the control necessary to: a) prevent infringement of its customs, fiscal, immigration or sanitary laws and regulations within its territory or territorial sea; b) punish infringement of the above laws and regulations committed within its territory or territorial sea. The contiguous zone may not extend beyond 24 nautical miles from the baselines from which the breadth of the territorial sea is measured (Article 33 (2)). Again, article 24 (1) of the 1958 Convention also states that, in a zone of the high seas contiguous to its territorial sea, the coastal State may exercise the control necessary to: a) Prevent infringement of its customs, fiscal, immigration or sanitary regulations within its territory or territorial sea; b) Punish infringement of the above regulations committed within its territory or territorial sea.

\section{Jurisdiction of the Coastal State in the Contiguous Zone}

If the coastal state notices that another state or person is violating its rights, or fleeing after committing any crime, or hampering the law and order situations in 
the contiguous zone area of the coastal state, then it has jurisdiction to prosecute and punish the perpetrator state. The relevant case in this respect is the Re Martinez Case (1959). The fact of the case was as follows: Under Article 2 of the Italian law of the sea (Maritime Code), from the baseline to 6 nautical miles area is Custom Zone and the next 6 nautical miles area is Vigilance Zone. Martinez involved himself in smuggling in the 9 kilometers area far from the base line of Italy. The Italian authority attempted to arrest him and fired him but he then escaped in 54 nautical miles in the sea. But ultimately he was captured by the Italian authority and his trial was commenced. Martinez argued that he has committed smuggling outside the territorial sea of Italy and he was arrested unlawfully. For this reason, Italy has no jurisdiction to try him. The prime issue in this case was, whether Italy has any jurisdiction to prosecute Martinez? The Appellate Court held that, the Italian Court has the jurisdiction to prosecute Martinez. The Court has the reasoning in this case that; the Vigilance Zone was made by Italy in order to maintain the security and good order in the coastal area and mainly to prevent smuggling in the coastal area.

\subsection{Exclusive Economic Zone (EEZ) or Patrimonial Sea}

Before discussing about the Exclusive Economic Zone (EEZ) or Patrimonial Sea, it is very much pertinent to mention an important case on this topic which will properly clarify the matter. Here the case is the Fisheries Jurisdiction Case (USA and Germany vs. Iceland; ICJ, 1974). In this case, in 1958 following the Geneva Conference, Iceland declared a 12 nautical miles exclusive fisheries zone and the UK accepted it in 1961. On $1^{\text {st }}$ September, 1972 Iceland announced 50 miles of its water territory for the conservation of economic zone measured from straight baseline close to all fisheries vessels. On $14^{\text {th }}$ April, 1972 the UK unilaterally inaugurated proceeding before the ICJ claiming that Iceland was not entitled to the unilateral extension of the zone. The UK further said that the conservation of fish stock of Iceland should be subject to bilateral arrangements between the two States. At that time, the court received another issue concerning the similar German-Iceland dispute. The Court joined them together.

In this case, the core issue before the Court was, whether Iceland was entitled to the unilateral extension of its economic zone 50 nautical miles beyond its territorial water? The court by 10 to 4 votes held that Iceland was not entitled to declare unilaterally an exclusive fisheries zone of 50 nautical miles beyond its territorial water. The governments of Iceland, the UK and West Germany were under an obligation to negotiate an equitable solution among them. The decision further said that the preferential rights of Iceland, the UK and West Germany should be taken into account in the negotiation. The reasoning in this case was that, the ICJ first established the principle of "preferential rights" over the particular regime of the sea. The Court held that, 90 percent foreign currency of Iceland is earned from fishing. In fact, the total economy of Iceland depends on the fishing. For this reason Iceland was given the preferential right over that particular zone. The Court found that the unilateral declaration of 50 nautical miles 
Exclusive Economic Zone (EEZ) neither legal nor illegal under the principle of international law. When the hearing of the case was going on before the ICJ, then the argument about the declaration of EEZ over the contiguous zone became the top issue of discussion regarding the delimitation of the international maritime area. For that reason many states claimed their right to fishing over 200 nautical miles towards the high seas. Finally this matter was emphasized and incorporated in the 1982 Convention and it was enacted that the EEZ shall extend to 200 nautical miles from the baseline of the coastal state, which was the reflection of the "creeping annexation rule" in international law. In Bangladesh context, the notification of $16^{\text {th }}$ April, 1974 declared that the EEZ of Bangladesh would extend to 200 nautical miles from the base line (Rashid, 2004).

\subsubsection{Clarification of the Concept of EEZ or Patrimonial Sea}

The concept of Exclusive Economic Zone (EEZ) or Patrimonial Sea was for the first time advocated by Kenya in the Asian-African Legal Consultative Committee at its Colombo Session held January, 1971 (Kapoor, 2008: p. 141). Article 55 of the 1982 convention provides that, the EEZ is an area beyond and adjacent to the territorial sea, subject to the specific legal regime established in this Part, under which the rights and jurisdiction of the coastal State and the rights and freedoms of other States are governed by the relevant provisions of this Convention. The EEZ is a belt of sea, adjacent to the coast, extending up to 200 miles from the baselines of the territorial sea. Within this area, the coastal state is given "sovereign rights" for the purpose of exploring and exploiting the living and non-living natural resources of the sea (Dixon, 2005: p. 203). Article 57 deals with the breadth of the exclusive economic zone and states that the exclusive economic zone shall not extend beyond 200 nautical miles from the baselines from which the breadth of the territorial sea is measured.

\subsubsection{Coastal State and Non-Coastal State: Rights and Obligations}

Article 56 contains provisions regarding the rights, jurisdiction and duties of the coastal State in the EEZ. Article 56 (1) states that, in the EEZ, the coastal State has: a) Sovereign rights for the purpose of exploring and exploiting, conserving and managing the natural resources, whether living or non-living, of the waters superjacent to the seabed and of the seabed and its subsoil, and with regard to other activities for the economic exploitation and exploration of the zone, such as the production of energy from the water, currents and winds; b) Jurisdiction as provided for in the relevant provisions of this Convention with regard to: i) the establishment and use of artificial islands, installations and structures; ii) marine scientific research; iii) the protection and preservation of the marine environment. Again, article 58 of the 1982 Convention deals with the rights and duties of other States in the EEZ which states that, in the exclusive economic zone, all States, whether coastal or land-locked, enjoy, subject to the relevant provisions of this Convention, the freedoms referred to in article 87 of navigation and over flight and of the laying of submarine cables and pipelines, and other internationally lawful uses of the sea related to these freedoms, e.g., those 
associated with the operation of ships, aircraft and submarine cables and pipelines, and compatible with the other provisions of this Convention (Article 58 (1), 1982).

\subsection{The High Seas}

The main stream of Grotian theory was that the high sea is res communis as it is physically impossible to take possession of it. Scelle has argued that the character of high sea can be compared to public parks or beaches or any open public place available to the public for general use under the domestic law (Khan, 2007: p. 241). Fenwick (1971: p. 496) opines that high sea or open sea is the sea outside the territorial waters. The high seas were defined in article 1 of the 1958 Geneva Convention on the High Seas as all parts of the sea that were not included in the territorial sea or in the internal waters of a state. In the view of recent developments, this definition has become very absolute and inadequate. This provision mainly replicates the customary international law, though in consequence of the developments the definition in article 86 of the 1982 Convention includes: “...all parts of the sea that are not included in the EEZ, in the territorial sea or internal waters of a State, or in the archipelagic waters of an archipelagic State...”. Article 87 of the 1982 Convention provides that high seas are open to all states and that the freedom of the high seas is exercised under the conditions laid down in the Convention and by other rules of international law.

\subsubsection{Freedoms of the High Sea: Explanation of the Idea}

In opposition to the principle of maritime sovereignty, the principle of the "freedom of the high seas" began to develop, as Hall (1924: p. 189) has pointed out, in accordance with the mutual and obvious interests of the maritime nations (Starke, 1994: p. 243). Article 2 of the Geneva Convention on the High Seas, 1958 provides that the freedom of the high seas comprises inter alia, both for the coastal and non-coastal states. There are four freedoms as has been mentioned in this Convention: 1) freedom of navigation, 2) freedom of fishing, 3) freedom to lay submarine cables and pipelines, and 4) freedom to fly over the high seas. These freedoms and others which are recognized by the general principles of international law shall be exercised by all states with regard to the interests of other states. In article 87 of the 1982 Convention two more freedoms were inserted. The freedoms of high seas expressly enumerated in article 87 (1) of the Convention are following: a) freedom of navigation; b) freedom of over flight; c) freedom to lay submarine cables and pipelines; d) freedom to construct artificial islands and other installations permitted under international law; e) freedom of fishing; f) freedom of scientific research. Article 87 (2) of the Convention states that, these freedoms shall be exercised by all States with due regard for the interests of other States in their exercise of the freedom of the high seas, and also with due regard for the rights under this Convention with respect to activities in the area. It is further provided that, the high seas shall be reserved for peaceful purposes (Article 88, 1982). 
No State may lawfully purport to subject any part of the high seas to its sovereignty (Article 89, 1982). Grotius, the father of international law was one of the first strenuously to attach the extensive claims to freedoms and sovereignty. His objections, as reflected in his famous book Mare Liberum, were based predominantly upon two grounds: 1) No ocean can be the property of a nation as it is impossible for any nation effectively to take it into possession by occupation; and 2) Nature does not give a right to anybody to appropriate things that may be used by everybody and are exhaustible. In other words, open sea is a res gentium or res extra commercium.

\subsubsection{Freedom of the Navigation in the High Sea: General Rules}

The freedom of navigation is a traditional and well established feature of the doctrine of the high seas, as is the freedom of fishing. Article 90 of the 1982 Convention contains provisions regarding right of navigation which reveals that, every State, whether coastal or land-locked, has the right to sail ships flying its flag on the high seas. Every State shall fix the conditions for the grant of its nationality to ships, for the registration of ships in its territory, and for the right to fly its flag. Ships have the nationality of the State whose flag they are entitled to fly. There must be the existence of a genuine link between the State and the ship (Article 91 (1), 1982).

Ships shall sail under the flag of one State only and, save in exceptional cases expressly provided for in international treaties or in this Convention, shall be subject to its exclusive jurisdiction on the high seas. A ship may not change its flag during a voyage or while in a port of call, save in the case of a real transfer of ownership or change of registry (Article 92 (1)). A ship which sails under the flags of two or more States, using them according to convenience, may not claim any of the nationalities in question with respect to any other State, and may be assimilated to a ship without nationality (Article 92 (2), 1982). The preceding articles do not prejudice the question of ships employed on the official service of the UN, its specialized agencies or the International Atomic Energy Agency (IAEA), flying the flag of the organization (Article 93, 1982). Every State shall effectively exercise its jurisdiction and control in administrative, technical and social matters over ships flying its flag (Article 94 (1)).

\subsubsection{Right to Hot Pursuit: Explanation of the Idea}

An exception to the exclusive jurisdiction of the flag state over a vessel in the high seas is the right of hot pursuit (Kapoor, 2008: p. 145). The right of hot pursuit of a foreign vessel is a principle designed to ensure that a vessel which has infringed the rules of a coastal state cannot escape punishment by fleeing to the high seas. In reality it means that in certain defined circumstances a coastal state may extend its jurisdiction onto the high seas in order to pursue and seize a ship which is suspected of infringing its laws. The right, which has been developing in one form or another since the $19^{\text {th }}$ century, was comprehensively elaborated in article 111 of the 1982 Convention, building upon article 23 of the 1958 High Seas Convention (Shaw, 1997: p. 425). Hot pursuit of a foreign vessel may be 
undertaken if there is good reason to believe that the vessel has violated the laws and regulations of the coastal state, but it must be commenced when the vessel or one of its boats is within the internal waters, archipelagic waters, the territorial sea or the contiguous zone, and may only be continued outside the territorial sea or contiguous zone if the pursuit has not been interrupted.

Pursuit is permissible only by the warships or military aircraft or other vessels or aircraft clearly marked and identifiable as being on government service and authorized to that effect (Starke, 1994: p. 279). Right of hot pursuit only begins when the pursuing ship has satisfied itself that the ship pursued or one of its boats is within the limits of the territorial sea or as the case may be in the contiguous zone, or EEZ or on the continental shelf (Article 111 (1), 1982). Article 23 of the 1958 Convention states that, if any warship does not comply with the regulations of the coastal State concerning passage through the territorial sea and disregards any request for compliance which is made to it, the coastal State may require the warship to leave the territorial sea. The right to hot pursuit ceases as soon as the vessel pursued has entered the territorial waters of its own or of a third state (Article 111 (3), 1982).

There is also huge debate in international law as to how far shall the coastal state use this right to hot pursuit. There is a famous case named I am Alone Case (1935) (Canada vs. USA) in this regard. In this case, on $20^{\text {th }}$ March, 1929 the "I am Alone", a rum runner of Canadian registry, was seen by the coast guard vessel Wolcott about 10.5 miles off the Louisiana coast, but within one hour sailing distance from the coast. The "I am Alone" ship refused to stop sailing when ordered by the Wolcott. Pursuit was taken up by the Dexter and Wolcott caught up with the "I am Alone" more than 200 miles off the coast of USA. After that when "I am Alone" refused to stop sailing the Dexter opened fire. Consequently the "I am Alone" was sunk. All but one person was rescued. In order to settle the dispute it was put before the two Commissioners appointed under the 1929 Convention. In this case, the core issues before the court was: 1) whether the pursing of US vessel Wolcott after the "I am Alone" was a hot pursuit? 2) Whether the US pursuit was reasonable or proportionate to the threat shown by the "I am Alone"? 3) If it would not be hot pursuit, whether US will be liable to pay compensation? The Commissioners held that the pursuing by the US vessel was not a hot pursuit. The opening fire by Wolcott was not justifiable. Thus the USA was ordered to pay compensation to Canada.

\subsection{Continental Shelf: Explanation of the Idea}

The term "continental shelf" is usually meant that part of the continental border which is between the shelf break and shoreline or, where there is no clear slope between the shoreline and the point where the depth of the superjacent water is around between 100 to 200 meters (UN, 2012). Continental shelf is a geological expression referring to the ledges that project from the continental land mass into the seas and which are covered with only a relatively shallow layer of water and which eventually fall away into the ocean depths. It is an underwater land- 
mass that extends from a continent, resulting in an area of relatively shallow water known as a shelf sea and a region adjoining the coastline of a continent, where the ocean is no more than a few hundred feet deep.

The legal concept of continental shelf came into attention since Truman Proclamation of 1945 wherein it was declared that the USA considered the resources of the shelf contiguous to the USA as appurtenant to the US and subject to its jurisdiction and control (Kapoor, 2008: p. 139). Article 76 (1) of the 1982 UN Convention defines "continental shelf" as follows:

"The continental shelf of a coastal State comprises the seabed and subsoil of the submarine areas that extend beyond its territorial sea throughout the natural prolongation of its land territory to the outer edge of the continental margin, or to a distance of 200 nautical miles from the baselines from which the breadth of the territorial sea is measured where the outer edge of the continental margin does not extend up to that distance" (Article 76 (1), 1982).

Where the continental margin extends beyond 200 miles, the Convention provides that the continental shelf should not extend more than 350 nautical miles from the baselines or 100 nautical miles from the 2500 meter depth. Again, the Convention on the Continental Shelf (1958) defined the "continental shelf" in the following terms:

"The continental shelf is (a) the seabed and sub-soil of the submarine areas adjacent to the coast but outside the territorial sea to a depth of 200 meters or 'beyond that limit to where the depth of the superjacent waters admits of the exploration of the natural resources of the said areas'; (b) to the seabed and sub-soil of similar submarine areas adjacent to the coast of island" (Article 1, 1958).

\section{Rights of the Coastal State over the Continental Shelf}

Article 77 of the 1982 Convention deals with the rights of the coastal State over the continental shelf and states: 1) The coastal State exercises over the continental shelf sovereign rights for the purpose of exploring it and exploiting its natural resources. 2) The rights are exclusive in the sense that if the coastal State does not explore the continental shelf or exploit its natural resources, no one may undertake these activities without the express consent of the coastal State. 3) The rights of the coastal State over the continental shelf do not depend on occupation, effective or notional, or on any express proclamation. 4) The natural resources consist of the mineral and other non-living resources of the seabed and subsoil together with living organisms belonging to sedentary species, that is to say, organisms which, at the harvestable stage, either are immobile on or under the seabed or are unable to move except in constant physical contact with the seabed or the subsoil.

The Convention expressly states that the rights of the coastal state do not affect the status of the superjacent waters as high seas, or that of the airspace above 
the waters (Article 78 of UN Convention, 1982 and article 3 of UN Convention, 1958). The question of the delimitation of the continental shelf has occasioned considerable debate and practice from the 1958 and 1982 Conventions to case laws and a variety of treaties (Shaw, 1997: p. 436). Most difficulties in this area are indeed resolved by agreement and the guiding principle of international law now is that disputes over continental shelf boundaries are to be settled by agreement in accordance with equitable principles. As regards the delimitation of the continental shelf between States with opposite or adjacent coasts, the Convention provides that it should be effected by agreement on the basis of international law; if no agreement can be reached within a reasonable period of time, the concerned States should resort to the procedures of settlement of disputes provided for in the Convention. From the various disputes among the states regarding the delimitation of the continental shelf, two significant principles have evolved in international law: a) Principle of Equidistance; and b) Principle of equity. Article 6 of the 1958 convention declared that in the absence of agreement and unless another boundary line was justified by special circumstances, the boundary should be determined "by application of the principle of equidistance from the nearest points of the baselines from which the width of the territorial sea of each state is measured." These two major principles are discussed below in the light of various cases of the international law of the sea.

In the North Sea Continental Shelf Case (1969) (Federal Republic of Germany vs. Denmark and Netherlands; ICJ), there were two bilateral agreements between the Federal Republic of Germany and the Netherlands and between the Federal Republic of Germany and Denmark. The two agreements were signed in 1964 and 1965 respectively and did no more that drawing a diving line for a short distance from the coastline beginning at the point at which the land boundary of the two States concerned was located. Further agreement for delimitation of their portion in the North Sea Continental Shelf had proved impossible and the parties of the said agreements put the dispute separately to the ICJ. Issues of this case were: 1) Which principle of international law shall be applied by the parties in the delimitation of water boundary? 2) Whether the provisions of Article 6 of the Geneva Convention on the Continental Shelf, 1958 (established on the principle of equidistance) shall be applicable on a State like Germany? The principle of equidistance is not applicable on the parties. The Court decided this case on the basis of equitable principle and the judgment goes in favor of Denmark and Netherlands. In this case the ICJ ruled against the existence of a customary rule which the Court in an earlier decision affirmed that the division of a common continental shelf of an adjacent country must be divided according to the equidistance principle (Khan, 2007: p. 471). The reasoning in this was that, as Germany did not ratify the Geneva Convention on the Continental Shelf of 1958, it is not bound to comply with the provisions of the convention. But after considering the matter, the court invented the new "principle of equity" in this case.

Another important case is the Anglo-French Continental Shelf Case (1978) (UK vs. France; ICJ). In this case, after the long attempt of about ten years (from 
1964-75), both the UK and France have failed to determine the area of their continental shelf. In 1975 a bilateral treaty was signed between them that, this matter shall be decided in the ICJ. Thus the ICJ has determined the area in Geneva in June, 1977. The main issue in the case was-on the basis of which principle or law the area of the continental shelf of both the States shall be determined? The ICJ delivered its decision on the basis of the principle of equity. The reasoning before the Court was that, it is not mandatory that the article 6 of the Geneva Convention on the Continental Shelf, 1958 (the principle of equidistance) must be applied in this case and for this reason a new principle, i.e., the principle of equity is applied here.

Again, in the Tunisia-Libya Continental Shelf Case (1982) (ICJ), a dispute arose between Tunisia and Libya in respect of delimitation of the respective area of continental shelf appertaining to each on the basis of the geology, physiographic and bathymetry. On $10^{\text {th }}$ June, 1977 both Tunisia and Libya entered into a treaty to go before the ICJ for the delimitation of the respective area of continental shelf. The ICJ was requested to deliver a judgment and it did so. But Tunisia filed a revision against the judgment of ICJ and the Revision Court upheld the previous judgment. Whether the Geneva Convention on the Continental Shelf, 1958 or the customary international law shall be applicable in deciding the case was the main issue in this case, as none of the States did ratify the Convention of 1958. The judgment of this case was delivered on the basis of the equitable principle. By a majority of ten to four votes the Court held that the delimitation method to be applied according to the principle of equity taking into account of all the relevant circumstances.

The Libya-Malta Continental Shelf Case (1985) is another significant case in this regard where a dispute arose between Libya and Malta in respect of delimitation of the areas of the continental shelf between Malta and Libya. Both the States were the signatory of the 1982 UN Convention on the Law of the Sea. But Libya was not a party to the 1958 Convention though Malta was. The main issue before the court was, whether article 6 (2) of the1958 Convention or the customary international law shall be applicable in deciding the case? Both of the States were signatory of the UN Convention on the Law of the Sea, 1982. By a majority of 14 to 3 votes the court held that the delimitation is to be applied in accordance with the principles of equidistance. In this case the ICJ followed the principle of equidistance for delimitation. Both the principles of equity and equidistance are applicable but it depends upon the peculiar geographical situation of the coastal state in concern. The Court said in this case an equitable result may be achievable by drawing a line of which every point is equidistant from the low water mark of the coast.

\section{Concluding Remarks}

It is apparent from the above scrutiny that the law of the sea is a burgeoning area of international law. The 1958 and 1982 Conventions on the Law of the Sea did much to create systematic and humdrum rules for the management and use of 
this common resource and many of the rules contained in these Conventions have now passed into customary international law. The great achievement was the conclusion of the 1982 UN Convention on the Law of the Sea which deals with about all the vital issues of the law of the sea and it does so in a manner that has commanded a significant amount of support. Also many of its provisions either reveal the existing customary international law or will crystallize into new law in due course.

\section{References}

Abdurrahim, W. (2012). Subjects of Public International Law. My International Law Studies. (In English)

Anglo-French Continental Shelf Case (UK vs. France; ICJ, 1978).

Anglo-Norwegian Fisheries Jurisdiction Case (England vs. Norway; ICJ, 1951).

Article 1. The Geneva Convention on the Continental Shelf, 1958.

Article 111 (1). UN Convention on the Law of the Sea, 1982.

Article 111 (3). UN Convention on the Law of the Sea, 1982.

Article 19 (2) (a) - (i). UN Convention on the Law of the Sea, 1982.

Article 2 (2). UN Convention on the Law of the Sea, 1982.

Article 2 (3). UN Convention on the Law of the Sea, 1982.

Article 21 (1) - (4). UN Convention on the Law of the Sea, 1982.

Article 27 (2). UN Convention on the Law of the Sea, 1982.

Article 58 (1). UN Convention on the Law of the Sea, 1982.

Article 76 (1). The UN Convention on the Law of the Sea, 1982.

Article 88. UN Convention on the Law of the Sea, 1982.

Article 89. UN Convention on the Law of the Sea, 1982.

Article 91 (1). UN Convention on the Law of the Sea, 1982.

Article 92 (2). UN Convention on the Law of the Sea, 1982.

Article 93. UN Convention on the Law of the Sea, 1982.

Brown, E. D. (1994). The International Law of the Sea (vol. 2). Oxford University Press.

Churchill, R. R. (2013). Law of the Sea. http://www.global.britannica.com

Churchill, R., \& Lowe, A. V. (1999). The Law of the Sea (3rd ed.). Huntington, NY: Juris Publishing, Inc.

Dixon, M. (2005). Textbook on International Law. New York, NY: Oxford University Press.

Fenwick, C. C. (1971). International Law (3rd Indian Reprint). Appleton-Century-Crofts. Fijens Case or Wildenhus Case (Belgium vs. USA, 1887) 120 U.S. 1 (1887).

Fisheries Jurisdiction Case (USA and Germany vs. Iceland; ICJ, 1974).

Gidel, A. (1930). La MerTerritorialeet la Zone Contigue, 48 HR.

Hall (1924). International Law (8th ed.). London: Stevens and Sons Ltd.

I am Alone Case (Canada v. United States) (1935). 3 R.I.A.A. 1609.

Kapoor, S. K. (2008). International Law and Human Rights [A Nutshell] (12th ed.). India: Central Law Agency.

Khan, A. (2007). International Law and Human Rights Bangladesh Perspective. Dhaka: 


\section{CCB Foundation.}

Khan, F. R. (2006). International Law of the Sea: Bangladesh Perspective. The Daily Star.

Libya-Malta Continental Shelf Case (1985). ICJ Rep 13 (Official Citation) ICGJ 118 (ICJ 1985) (OUP Reference).

Lowe, A. V. (1981). The Development of the Concept of the Contiguous Zone, 52 BYIL.

North Sea Continental Shelf Cases (Federal Republic of Germany v. Denmark; Federal Republic of Germany v. Netherlands) I.C.J. 1969 I.C.J. 3.

O'Connell, D. P. (1982). The International Law of the Sea (Vol. 2). Oxford: Oxford University Press.

Rahman, M. (2003). International Law in a Changing World. Dhaka: PololProkashoni.

Rashid, H. U. (2004). Why Do States Comply with International Law? The Daily Star.

Re Martinez Case (1959). (52 Cal.2d 808) [Crim. No. 6343. In Bank. Oct. 30, 1959].

Reisman, W. M., \& Westerman, G. S. (1992). Straight Baselines in International Maritime Boundary Delimitation. New York, NY: Palgrave Macmillan.

Rex vs. Anderson (1868). 11 Cox Crim Cases 198 (Court of Criminal Appeal, England).

Shaw, M. N. (1997). International Law. Cambridge: Cambridge University Press.

Sircar, M. J. (1997). Glimpses of International Law. Dhaka: Form International.

Starke, J. G. (1994). AnIntroduction to International Law (10th ed.). New Delhi: Aditya Books.

State vs. Yannopulous (Italy vs. Greece, 1974).

Treves, T. (2013). UN Convention on the Law of the Sea Montego Bay. UN Office of the Legal Affairs.

Tunisia-Libya Continental Shelf Case (ICJ, 1982) 1982 I.C.J. 18.

UN (2012). Commission on the Limits of the Continental Shelf (CLCS). Division for Ocean Affairs and the Law of the Sea, Office of Legal Affairs, United Nations.

\section{Submit or recommend next manuscript to SCIRP and we will provide best} service for you:

Accepting pre-submission inquiries through Email, Facebook, LinkedIn, Twitter, etc. A wide selection of journals (inclusive of 9 subjects, more than 200 journals)

Providing 24-hour high-quality service

User-friendly online submission system

Fair and swift peer-review system

Efficient typesetting and proofreading procedure

Display of the result of downloads and visits, as well as the number of cited articles

Maximum dissemination of your research work

Submit your manuscript at: http://papersubmission.scirp.org/

Or contact blr@scirp.org 